\title{
Литвищенко Я.В., Мамин А.С. \\ Система органов внутренних дел, осуществляющих административный надзор за лицами, освобожденными из мест лишения свободы
}

Белгородский государственный национальный исследовательский университет (Россия, Белгород)

doi: 10.18411/lj-04-2021-236

\section{Аннотация}

Данная статья направлена на рассмотрение системы ОВД, осуществляющих административный надзор за поднадзорными лицами. Авторы рассматривают порядок и последовательность установления административного надзора.

Ключевые слова: административный надзор, поднадзорное лицо, структура организации работы по осуществлению административного надзора.

\section{Abstract}

This article is aimed at reviewing the system of Internal Affairs bodies that exercise administrative supervision over supervised persons. The authors consider the order and sequence of establishing administrative supervision.

Keywords: administrative supervision, supervised person, structure of the organization of work on the implementation of administrative supervision.

Говоря об административном надзоре за лицами, освобожденными из мест лишения свободы, в первую очередь, необходимо отметить, что такой надзор относится к деятельности полиции. Полиция, являясь структурной частью органов внутренних дел, выполняет надзорные функции.

По мнению авторов, целью административного надзора является контроль сотрудниками органов внутренних органов за лицами, освобожденными из мест лишения свободы, а также воздействие воспитательного характера на них с последующим предупреждением совершения рецидивных преступлений. Достижение данной цели возможно обеспечить только совместным участием в данной деятельности различных субъектов на достаточно высоком и компетентном уровне. Для должного выполнения задач необходимо использование специальных методов и средств, что предполагает создание системы, основанной на принципе подчиненности«управляющая система воздействует на управляемую». Результативные и качественные характеристики административного надзора зависят от эффективной и четко выстроенной организации. Необходимо проведение таких мероприятий, как служебные совещания, собрания, инструктажи, организация взаимодействия между сотрудниками и подразделениями, обобщение и распространение положительного опыта, обучение исполнителей и оказание им практической помощи. При проведении подобных организационных мер, субъект управления воздействует на объект и доводит необходимую информацию, то есть происходит управленческое воздействие, направленное на совершение определенных действий.

В современных условиях, система органов внутренних дел Российской Федерации развивается и совершенствуется с большой динамичностью, ориентированной на устойчивое и мобильное обеспечение всей звеньев данной системы.

Достижение обеспечения качественного функционирования данной системы зависит от расстановки приоритетов сотрудников, наиболее простой и гибкой организационной структуры. Руководство и внутриорганизационное регулирование осуществляется на основе выработки, усовершенствовании нормативных документов, которые носят подзаконный характер.

Обязанности по осуществлению надзора возложены на сотрудников полиции и, соответственно, основные функции по организации и осуществлению административного надзора выполняют их территориальные органы. 
Законодательством Российской Федерации определены порядок и последовательность установления административного надзора, которые заключаются в следующем:

- После поступления из УФСИН сообщения об освобождении лица, в отношении которого будет осуществляться индивидуальный надзор, поступившие документы регистрируются в отделе (отделении, группе) ДиР и незамедлительно передаются начальнику территориального органа внутренних дел для рассмотрения. После резолюции начальника сообщение в течение одного рабочего дня передается в подразделение административного надзора либо сотруднику, на которого возложены обязанности по контролю и осуществлению профилактической работы с данной категорией лиц.

- В отношении поднадзорного лица заводится дело административного надзора, такое дело ведется и хранится у сотрудника по надзору согласно установленным законодательством правилам.

- В течение одного рабочего дня информация о назначении административного надзора и постановки на учет в подразделения и службы, которые принимают участие в контроле за данными лицами, подобная информация ежемесячно обновляется.

- На протяжении всего периода административного надзора с лицом проводятся профилактические работы

лиц.

Сведения о лицах, взятых на учет вносятся в журнал регистрации поднадзорных

Говоря о субъектах, принимающих участие в таком надзоре необходимо указать следующие: сотрудники подразделений УУП, полицейские подразделений ППС, сотрудники ДПС ГИБДД, сотрудники вневедомственной охраны, сотрудники уголовного розыска и т.д.

Рассмотрим в схематичном виде структуру организации работы по обеспечению административного надзора на уроне МВД РФ, региональном и районном уровнях.

Схема структуры организации работы по осуществлению административного надзора на уровне МВД РФ необходимо представить следующем виде:

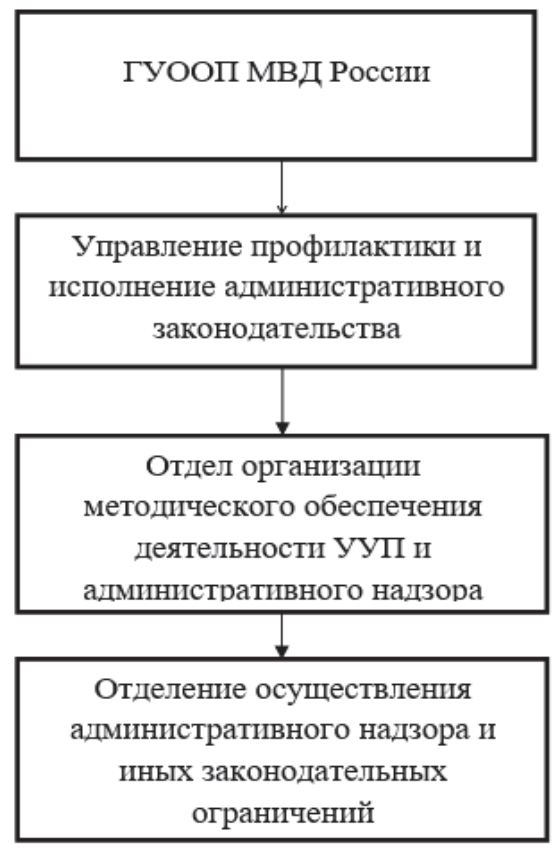

Схема структуры организации работы по осуществлению административного надзора на региональном уровне представлена в следующем виде: 


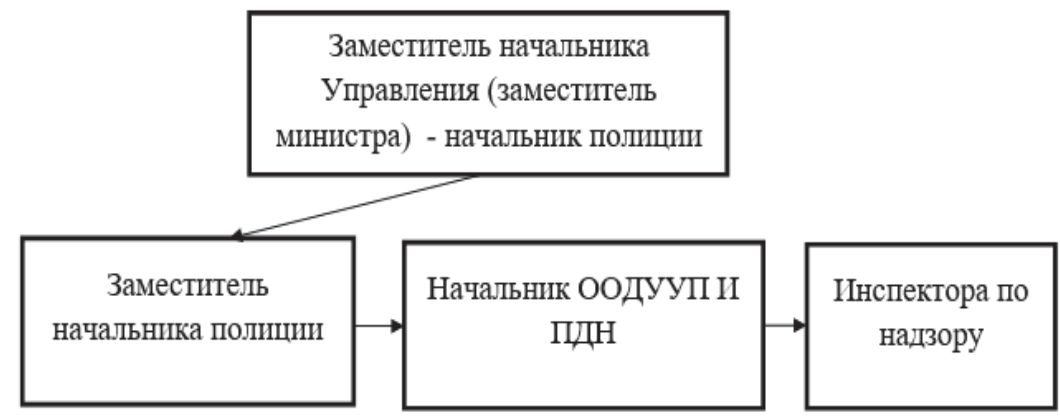

Схема структуры организации работы по осуществлению административного надзора в органах внутренних дел на районном уровне выглядит таким образом:

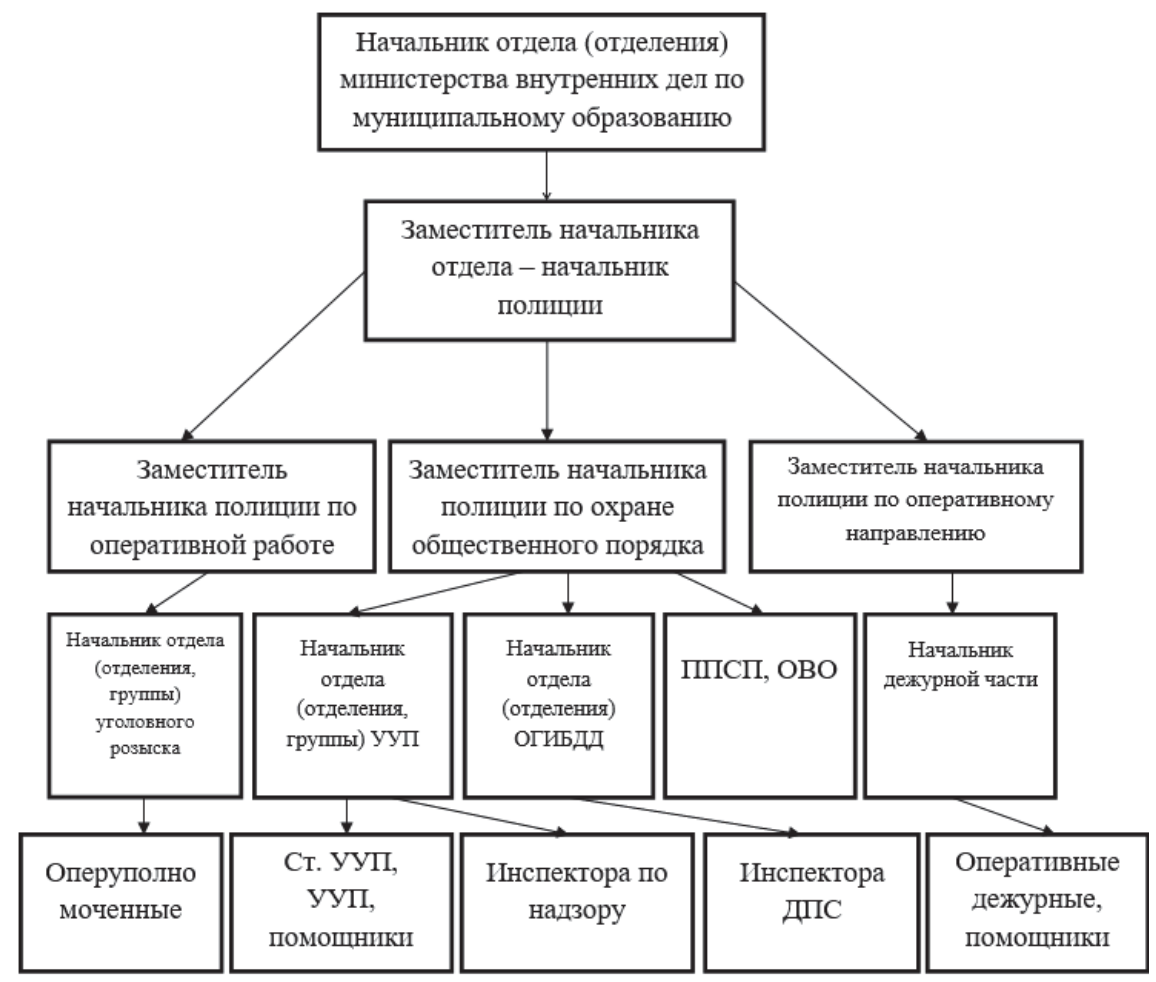

Однако, несмотря на то, что механизм по обеспечению должного административного надзора совершенствуется, статистика ГИАЦ МВД РФ показывает, что количество поднадзорных лиц ежегодно растет, что свидетельствует о недостаточно развитой нормативно-правовой базы, добросовестного исполнения должностных обязанностей и т.д.

Субъекты, осуществляющие административный надзор, за лицами, освобожденными из мест лишения свободы, выполняют огромное количество обязанностей, которые предусмотрены должностной инструкцией, например, в обязанности участковых входит выявление и предупреждение преступлений и административных правонарушений, проведение поквартирного обхода, проверка условий хранения оружия, рассмотрение заявлений и обращений граждан и т.д.

Таким образом, отсутствие штатных должностей инспекторов по административному надзору влияет на качество, проводимой профилактической работы с поднадзорными лицами, соответственно, ухудшаются результаты оперативнослужебной деятельности сотрудника, на которого возложены обязанности инспектора по административного надзору, по основному месту службы по должности. Авторы считают необходимым расширить круг субъектов, участвующих в осуществлении 
административного надзора для получения большей эффективности предупреждения рецидивной преступности.

$$
* * *
$$

1. Конституция Российской Федерации (принята всенародным голосованием 12.12 .1993 с изменениями, одобренными в ходе общероссийского голосования 01.07.2020) // Официальный интернет-портал правовой информации. - URL: http://www.pravo.gov.ru. (дата обращения: 23.03.2021).

2. Об административном надзоре за лицами, освобожденными из мест лишения свободы: Федеральный закон от 06.04.2011 № 64-Ф3 (ред. от 01.10.2019) // Собрание законодательства РФ. 11.04.2011. - № 15. - ст. 2037.

3. Кодекс Российской Федерации об административных правонарушениях от 30.12.2001 № $195-$-Ф3 (ред. от 17.02.2021) // Собрание законодательства РФ. - 2002. - № 1 (ч. 1). ст. 1.

4. Административное право: учебник под ред. Л.Л. Попова, М.С. Студеникиной. - М.: Норма, 2017. C.411

5. Мелехин А. В. Административное право Российской Федерации: учебник - М.: Московская финансово - промышленная академия, 2018. С. 274-275

\section{Марченко А.В., Марченко В.В. \\ Актуальные вопросы проведения прений сторон в ходе судебного разбирательства}

Санкт-Петербургский государственный морской технический университет doi: 10.18411/lj-04-2021-237

(Россия, Санкт-Петербург)

\section{Аннотация}

В настоящей статье, авторы на основе современной судебной практики, с учетом правовых позиций Верховного Суда Российской Федерации, рассматривают наиболее актуальные вопросы и порядок их решения в ходе прений сторон, в судебном разбирательстве уголовного дела.

Ключевые слова: уголовный процесс, Пленум Верховного Суда Российской Федерации, прения, прения сторон, государственный обвинитель, защитник, равенство сторон.

\section{Abstract}

The summary: In this article, the authors, on the basis of modern judicial practice, taking into account the legal positions of the Supreme Court of the Russian Federation, consider the most pressing issues and the procedure for their resolution during the disputations of the parties, in the trial of a criminal case.

Key words: criminal proceedings, Plenum of the Supreme Court of the Russian Federation, disputations, debates of the parties, public prosecutor, defender, equality of the parties.

Стадия судебного разбирательства является центральной, основной стадией уголовного процесса, квинтэссенцией уголовного судопроизводства, именно на этой стадии осуществляется правосудие, судом первой инстанции рассматривается дело по существу, решается вопрос о виновности или невиновности подсудимого, назначении ему наказания или освобождении от него. Именно на этой стадии в полной мере реализуется назначение уголовного судопроизводства, проявляется действие всех принципов уголовного процесса, определяющих его демократический характер.

По мнению большинства ученых, судебное разбирательство представляет собой систему процессуальных действий суда и других участников уголовного процесса, совершаемых в определенной последовательности. В структуре судебного разбирательства, как правило, выделяют четыре этапа: подготовительную часть, 